\title{
Evidence for Active Maternofetal Transfer of Magnesium across the in Situ Perfused Rat Placenta
}

\author{
A. J. SHAW, M. Z. MUGHAL, T. MOHAMMED, M. J. A. MARESH, AND C. P. SIBLEY \\ Departments of Child Health [A.J.S., M.Z.M., T.M., C.P.S.], Physiological Sciences [A.J.S., C.P.S.], and \\ Obstetrics \& Gynaecology [M.J.A.M.], University of Manchester, St. Mary's Hospital, Manchester, M13 OJH, \\ England, United Kingdom
}

\begin{abstract}
Mechanisms of maternofetal Mg transfer have been investigated across the in situ perfused rat placenta at 21 d gestation (term $=23 \mathrm{~d}$ ). The fetal placental circulation was perfused with Mg-free Krebs-Ringer solution and clearance of $\mathrm{Mg}$ from maternal plasma across the placenta [unidirectional maternofetal clearance $\left(K_{m f}\right) \mathbf{M g}$ ] compared with that for ${ }^{45} \mathrm{Ca}$ and ${ }^{51} \mathrm{Cr}$-EDTA, the latter being used as a diffusional marker. Because diffusion coefficients determined for these solutes were similar $(6.8-7.6$ $\left.\times 10^{-6} \mathrm{~cm}^{2} \cdot \mathrm{sec}^{-1}\right)$, greater $\mathrm{K}_{\mathrm{mf}}$ values determined for $\mathrm{Mg}$ and ${ }^{45} \mathrm{Ca}$ (mean \pm SD: $26.7 \pm 9.2$ and $93.1 \pm 29.8 \mu \mathrm{L}$. $\mathrm{min}^{-1} \cdot \mathrm{g}^{-1}$ placenta, respectively) compared to ${ }^{51} \mathrm{Cr}$-EDTA $\left(3.2 \pm 0.9 \mu \mathrm{L} \cdot \mathrm{min}^{-1} \cdot \mathrm{g}^{-1}\right)$ suggest that maternofetal transfer of these cations occurs by mechanisms in addition to diffusion. $K_{m f} M g$ was also greater than $K_{m f}{ }^{51} \mathrm{Cr}$-EDTA when measured across the dually perfused rat placenta, in which the maternal uterine artery was additionally perfused with Mg-containing ( $\left.0.5 \mathrm{mmol} \cdot \mathrm{L}^{-1}\right)$ Krebs-Ringer solution. Decreasing the $\mathrm{Mg}$ concentration in the maternal perfusate by $90 \%$ reduced $\mathrm{Mg}$ appearance in the fetal perfusate by $87 \%$ within $8 \mathrm{~min}$; this suggests that $K_{\mathrm{mf}} \mathbf{M g}$ across the in situ perfused placenta largely reflects $\mathrm{Mg}$ transfer from maternal plasma and not simply elution of a placental $\mathrm{Mg}$ pool. Addition of $\mathrm{KCN}\left(1 \mathrm{mmol} \cdot \mathrm{L}^{-1}\right)$ to the fetal perfusate or lowering perfusate temperature from 37 to $26^{\circ} \mathrm{C}$ significantly reduced $\mathrm{K}_{\mathrm{mf}} \mathrm{Mg}$ and $\mathrm{K}_{\mathrm{mf}}{ }^{45} \mathrm{Ca}$ across the in situ perfused placenta. In contrast, $\mathrm{K}_{\mathrm{mf}}{ }^{51} \mathrm{Cr}$-EDTA was increased by $\mathrm{KCN}$ and unaffected by temperature. Both total and ultrafiltrable $\mathrm{Mg}$ concentrations were higher in fetal compared with maternal plasma, indicating that maternofetal Mg transfer occurs against a chemical gradient. These data collectively suggest that maternofetal transfer of $\mathrm{Mg}$, as well as that of $\mathrm{Ca}$, is dependent on placental metabolism. (Pediatr Res 27: 622-625, 1990)
\end{abstract}

\section{Abbreviations}

D, diffusion coefficient

$\mathbf{K}_{\mathrm{m} f}$, unidirectional maternofetal clearance Pd, potential difference

$\mathrm{Mg}$ concentrations are reported to be higher in fetal compared with maternal plasma in rats $(1,2)$, rabbits (3), sheep (4) and humans $(5,6)$. Furthermore, studies in rats indicate that this

Received November 6, 1989; accepted February 7, 1990.

Correspondence: Dr. A. J. Shaw, Department of Child Health, St. Mary's Hospital, University of Manchester, Manchester M13 OJH, England, UK.

Supported by Birthright. gradient does not reflect greater protein binding in fetal plasma, ultrafiltrable $\mathrm{Mg}$ concentrations also being higher in fetal compared with maternal plasma (1). These observations indicate that placental transfer of $\mathrm{Mg}$ from mother to fetus must occur against a chemical gradient. Using ${ }^{28} \mathrm{Mg}$, Care et al. (4) determined maternofetal and fetomaternal $\mathrm{Mg}$ fluxes of 0.042 and 0.012 $\mathrm{mg} \cdot \mathrm{h}^{-1} \cdot \mathrm{kg}^{-1}$ fetus, respectively, in sheep at $13 \mathrm{~d}$ preterm. These fluxes suggest the presence of an active mechanism for the maternofetal transfer of $\mathrm{Mg}$.

In our study, maternal and fetal plasma $\mathrm{Mg}$ concentrations (total and ultrafiltrable) were measured in the near term rat and maternofetal $\mathrm{Mg}$ transfer was investigated using the in situ (umbilically) perfused rat placenta preparation (7). $\mathrm{K}_{\mathrm{mf}}$ of ${ }^{24} \mathrm{Mg}$ was compared with that of ${ }^{51} \mathrm{Cr}$-EDTA, used as a diffusional marker (7), and also with that of ${ }^{45} \mathrm{Ca}$, a divalent cation with which $\mathrm{Mg}$ may share transcellular transport systems (8). Previous studies (9) suggest that $\mathrm{Ca}$ is actively transferred across the in situ perfused rat placenta. The effects of adding $\mathrm{KCN}$ to the perfusion fluid or decreasing perfusate temperature were therefore examined for effects on possible active placental transfer of $\mathrm{Mg}$ as well as of ${ }^{45} \mathrm{Ca}$. Experiments were also performed using a dually perfused rat placenta in which the maternal uterine artery was additionally perfused with Krebs Ringer solution with or without $\mathrm{Mg}$ (10). These were performed to confirm that Mg transfer (as measured using the in situ perfused placenta) reflects maternofetal transfer and not simply elution of a placental $\mathrm{Mg}$ pool. A preliminary report of this work has appeared elsewhere (11).

\section{MATERIALS AND METHODS}

Plasma $\mathrm{Mg}$ determinations. Pregnant Sprague Dawley rats (300-400 g body wt) were anesthetized by intraperitoneal injection of $110 \mathrm{mg} \cdot \mathrm{kg}^{-1}$ sodium thiobutabarbital (Inactin, BYK Gulden, Hamburg, FRG) on d 21 of gestation (term $=23 \mathrm{~d}$ ). After laparotomy, a maternal blood sample $(2-3 \mathrm{~mL})$ was withdrawn from the inferior vena cava using a 23-gauge needle. Hysterotomy was then performed and a fetus delivered. Fetal blood $(0.3-0.5 \mathrm{~mL})$ was withdrawn by gentle suction into a plastic tube connected to a 24-gauge needle inserted into the umbilical artery (12). This method causes minimal cell damage since maternal blood obtained from the inferior vena cava using this device had a similar plasma $\mathrm{Mg}$ concentration to that obtained as above. Heparinized blood samples were centrifuged ( $2000 \mathrm{rpm}$ for $2 \mathrm{~min}$ ) and plasma from four to six fetuses pooled. To remove protein bound $\mathrm{Mg}$, samples $(300 \mu \mathrm{L})$ of plasma were further centrifuged $(1000 \mathrm{rpm}$ for $15 \mathrm{~min})$ in ultrafiltrate tubes (Amicon, Gloucester, UK). After appropriate dilution in 5\% $\mathrm{LaCl}_{2}$ solution, $\mathrm{Mg}$ concentrations were determined by atomic absorption spectrophotometry (Perkin Elmer 2380, Perkin Elmer Corp., Norwalk, CT; linear working range up to $80 \mu \mathrm{mol} \cdot \mathrm{L}^{-1}$ $\mathrm{Mg}$; sensitivity $0.3 \mu \mathrm{mol} \cdot \mathrm{L}^{-1} \mathrm{Mg}$ for $1 \%$ absorption). Plasma 
total and ultrafiltrable $\mathrm{Mg}$ concentrations were also measured in nonpregnant female Sprague Dawley rats.

Placental perfusion procedure. Pregnant Sprague Dawley rats were anesthetized as above on d 21 of gestation and the trachea, a jugular vein (for tracer administration), and a carotid artery (for monitoring maternal blood pressure and blood sampling) cannulated. The rat was then immobilized on its back in a thermostated $\left(37^{\circ} \mathrm{C}\right)$ bath of isotonic saline. After laparotomy and hysterotomy, a fetus was delivered and its umbilical artery and vein cannulated as previously described (7). The placenta was perfused $\left(500 \mu \mathrm{L} \cdot \mathrm{min}^{-1}\right)$ with $\mathrm{Mg}$-free Krebs-Ringer solution containing: (mmol $\cdot \mathrm{L}^{-1}$ ) $\mathrm{NaCl} 118, \mathrm{KCl} 4.7, \mathrm{NaHCO}_{3}$ 24.9, $\mathrm{CaCl}_{2} \cdot 2 \quad \mathrm{H}_{2} \mathrm{O} 1.40, \mathrm{KH}_{2} \mathrm{PO}_{4} 1.18$, D-glucose $0.2 \%$, Dextran (40 $000 \mathrm{~mol} w \mathrm{wt}) 3.5 \%$, pH 7.4 adjusted by continuous gassing with $95 \% \mathrm{O}_{2}, 5 \% \mathrm{CO}_{2}$. The solution was warmed to $37^{\circ} \mathrm{C}$ using a heat exchanger prior to perfusion. Perfusion pressure was monitored via a side arm in the arterial catheter. For $\mathrm{K}_{\mathrm{mf}}$ determination (see below), tracers $\left(10 \mu \mathrm{Ci}^{45} \mathrm{CaCl}_{2}, 0.071 \mathrm{mg} \mathrm{Ca}\right.$. $\mathrm{mL}^{-1} ; 50 \mu \mathrm{Ci}{ }^{51} \mathrm{Cr}$-EDTA, Amersham International, Buckinghamshire, UK) were injected at time zero and maternal blood samples $(0.5 \mathrm{~mL})$ taken at $2,12,24,36$, and $44 \mathrm{~min}$. Consecutive 4-min collections of fetal venous effluent were made between 3 and $43 \mathrm{~min}$. Aliquots of plasma $(50 \mu \mathrm{L})$ and perfusate collections $\left(0.4 \mathrm{~mL}\right.$ ) were analyzed for ${ }^{45} \mathrm{Ca}$ (Packard Tricarb $2000 \mathrm{CA}$ counter, Packard Instrument Co., Inc., Downers Grove, IL) and ${ }^{51} \mathrm{Cr}$-EDTA (Packard Autogamma 800 counter). Since the $\mathrm{Mg}$ isotope $\left(\mathrm{Mg}^{28}\right)$ was not available, $\mathrm{K}_{\mathrm{mf}} \mathrm{Mg}$ was determined by measuring ${ }^{24} \mathrm{Mg}$ in plasma samples and that transferred to the $\mathrm{Mg}$ free perfusate by atomic absorption spectrophotometry. Plasma samples were diluted 100 -fold and perfusate samples 5fold with $0.5 \% \mathrm{LaCl}_{2}$ solution to obtain $\mathrm{Mg}$ in the assay range. Background concentrations of $\mathrm{Mg}$ in the perfusion fluid was always $<10 \%$ that in perfusate effluent. In some experiments, the effect of changing to a $\mathrm{KCN}$-containing $\left(1 \mathrm{mmol} \cdot \mathrm{L}^{-1}\right)$ perfusate or rapidly cooling perfusate temperature from $37^{\circ} \mathrm{C}$ to $26^{\circ} \mathrm{C}$ (by addition of cold water to the heat exchanger) on $\mathrm{K}_{\mathrm{mf}}$ values was investigated. The criteria for a successfully perfused placenta were as previously described (7).

$\mathrm{K}_{\mathrm{mf}}$ for $\mathrm{Mg}$ and ${ }^{51} \mathrm{Cr}$-EDTA were also determined across rat placentas in which the maternal uterine artery as well as the umbilical circulation was perfused (dual perfusion). The uterine artery was catheterized (24-gauge) and perfused at $1.8 \mathrm{~mL} \cdot \mathrm{min}^{-1}$ with $\mathrm{Mg}$-containing $\left(0.5 \mathrm{mmol} \cdot \mathrm{L}^{-1}\right)$ Krebs-Ringer solution (other constituents as above). Maternal blood vessels to placentas other than that being perfused were ligated; maternal effluent was allowed to drain from an incision in the uterine vein (10).

Diffusion coefficients. These were determined for $\mathrm{Mg},{ }^{45} \mathrm{Ca}$, and ${ }^{51} \mathrm{Cr}$-EDTA using the method of Berhe et al. (13), in which $2-\mathrm{mL}$ syringes with injection ends cut off were filled with a $1 \%$ agar solution containing $150 \mathrm{mmol} \cdot \mathrm{L}^{-1} \mathrm{NaCl}, 40 \mathrm{mmol} \cdot \mathrm{L}^{-1}$ $\mathrm{CaCl}_{2}$ and placed in a stirred medium of $150 \mathrm{mmol} \cdot \mathrm{L}^{-1} \mathrm{NaCl}$, $40 \mathrm{mmol} \cdot \mathrm{L}^{-1} \mathrm{MgCl}_{2}$ with $0.2 \mu \mathrm{Ci} \mathrm{mL}{ }^{-1}{ }^{45} \mathrm{CaCl}_{2}(0.071 \mathrm{mg} \mathrm{Ca}$. $\left.\mathrm{mL}^{-1}\right), 0.4 \mu \mathrm{Ci} \cdot \mathrm{mL}^{-1}{ }^{51} \mathrm{Cr}$-EDTA and maintained at $37^{\circ} \mathrm{C}$ for 4 $\mathrm{hr}$. The cylinder of gel was then expelled and cut with a razor blade into $1-\mathrm{mm}$ sections that were each allowed to equilibrate in $2.5 \mathrm{~mL}$ of a $0.5 \% \mathrm{LaCl}_{2}$ solution. The concentration of ${ }^{45} \mathrm{Ca}$ and ${ }^{51} \mathrm{Cr}$-EDTA $\left(\mathrm{cpm} \cdot \mathrm{mL}^{-1}\right)$, and of $\mathrm{Mg}\left(\mathrm{mmol} \cdot \mathrm{L}^{-1}\right)$ in each slice was then determined (as above) and diffusion coefficients estimated by nonlinear regression as previously described (13).

Calculations and statistics. $\mathrm{K}_{\mathrm{mf}}$ for $\mathrm{Mg},{ }^{45} \mathrm{Ca}$, and ${ }^{51} \mathrm{Cr}$-EDTA were calculated using the equation

$$
\mathrm{K}_{\mathrm{mf}}=\frac{[\mathrm{v}] \mathrm{Q}}{[\mathrm{A}] \mathrm{wt}} \mu \mathrm{L} \cdot \mathrm{min}^{-1} \cdot \mathrm{g}^{-1}
$$

where $[\mathrm{v}]$ is the isotope or $\mathrm{Mg}$ concentration in the umbilical vein effluent (background perfusate $\mathrm{Mg}$ subtracted), [A] is the corresponding concentration in maternal plasma (estimated for the midpoint of each collection period) or uterine arterial per- fusate (in the dually perfused preparation), $Q$ is the fetal perfusate flow rate, and wt is the placental wet wt.

Data are shown as mean \pm SEM or \pm SD where appropriate and statistical comparisons have been made using $t$ tests, paired or unpaired as appropriate.

\section{RESULTS}

As shown in Table 1, total and ultrafiltrable Mg concentrations were both lower in maternal compared with fetal rat plasma at $21 \mathrm{~d}$ gestation. Maternal plasma $\mathrm{Mg}$ concentrations were also lower than those in the nonpregnant female. However, in each case, $64-65 \%$ of plasma total $\mathrm{Mg}$ was ultrafiltrable.

$\mathrm{K}_{\mathrm{mf}}$ (across the in situ perfused placenta in rats maintained at $37^{\circ} \mathrm{C}$ ) and $\mathrm{D}$ values for $\mathrm{Mg},{ }^{45} \mathrm{Ca}$, and ${ }^{51} \mathrm{Cr}$-EDTA are shown in Table $2 . \mathrm{K}_{\mathrm{mf}}$ for the first three effluent periods were averaged; there was little change in $\mathrm{K}_{\mathrm{mf}}$ values for any solute with time up to 15 min (Figs. 1 and 2). Mean \pm SD placental and fetal wt were $0.50 \pm 0.05 \mathrm{~g}$ and $4.12 \pm 0.55 \mathrm{~g}$, respectively $(n=21)$. D for these solutes were of a similar order of magnitude, whereas $\mathrm{K}_{\mathrm{mf}}$ for $\mathrm{Mg}$ and ${ }^{45} \mathrm{Ca}$ were markedly greater than for the diffusional marker ${ }^{51} \mathrm{Cr}$-EDTA. This is reflected by higher $\mathrm{K}_{\mathrm{mf}} / \mathrm{D}$ ratios for $\mathrm{Mg}$ and ${ }^{45} \mathrm{Ca}$ compared with ${ }^{51} \mathrm{Cr}$-EDTA.

The effects of adding $\mathrm{KCN}$ to the fetal perfusate $\left(1 \mathrm{mmol} \cdot \mathrm{L}^{-1}\right.$ final concentration) or lowering perfusate temperature from 37 $\pm 1{ }^{\circ} \mathrm{C}$ to $26 \pm 1{ }^{\circ} \mathrm{C}$ on $\mathrm{K}_{\mathrm{mf}}$ for $\mathrm{Mg},{ }^{45} \mathrm{Ca}$, and ${ }^{51} \mathrm{Cr}$-EDTA are shown in Figures 1 and 2, respectively. Data are expressed as a percentage of the first collection period. In all cases, $\mathrm{K}_{\mathrm{mf}}$ for $\mathrm{Mg}$, ${ }^{45} \mathrm{Ca}$, and ${ }^{51} \mathrm{Cr}$-EDTA during this period were similar to those in Table 2 and $\mathrm{K}_{\mathrm{mf}}$ values did not significantly differ between control and treatment groups at this time. $\mathrm{K}_{\mathrm{mf}}$ for $\mathrm{Mg}$ and ${ }^{45} \mathrm{Ca}$ were each significantly reduced within $15 \mathrm{~min}$ of $\mathrm{KCN}$ addition compared with controls. In contrast, $\mathrm{K}_{\mathrm{mf}}{ }^{51} \mathrm{Cr}$-EDTA was increased by this treatment (Fig. 1). Decreasing perfusate temperature also reduced $\mathrm{K}_{\mathrm{mf}}$ for $\mathrm{Mg}$ and ${ }^{45} \mathrm{Ca}$ compared with controls, whereas $\mathrm{K}_{\mathrm{mf}}{ }^{51} \mathrm{Cr}$-EDTA was not significantly affected (Fig. 2).

$\mathrm{K}_{\mathrm{mf}} \mathrm{Mg}$ and $\mathrm{K}_{\mathrm{mf}}{ }^{51} \mathrm{Cr}$-EDTA measured using the dually perfused rat placenta $(n=4)$ were $52.7 \pm 18.4$ (mean \pm SD) and $9.7 \pm 10.0 \mu \mathrm{L} \cdot \mathrm{min}^{-1} \cdot \mathrm{g}^{-1}$ placenta, respectively; these values are greater than those determined using the in situ perfused preparation (Table 2). Reducing $\mathrm{Mg}$ concentration in the uterine arterial perfusate by $90 \%$ was paralleled by an $86 \%$ decrease in $\mathrm{Mg}$ concentration in the fetal perfusate effluent within $8 \mathrm{~min}$

Table 1. Plasma $M g$ concentrations $\left(\mathrm{mmol} \cdot \mathrm{L}^{-1}\right)$ in rats*

\begin{tabular}{lcc}
\hline & Total & Ultrafiltrable \\
\hline Nonpregnant female & $0.79 \pm 0.04 \dagger$ & $0.51 \pm 0.03 \dagger$ \\
& & $(65 \%)$ \\
Maternal & $0.55 \pm 0.02$ & $0.36 \pm 0.02$ \\
& & $(65 \%)$ \\
Fetal & $0.84 \pm 0.01 \ddagger$ & $0.54 \pm 0.04 \dagger$ \\
& & $(64 \%)$ \\
\hline
\end{tabular}

* Data are mean \pm SEM. Percent ultrafiltrable $\mathrm{Mg}$ are in parentheses ( $n=8 /$ group).

$\dagger$ Significance compared to maternal concentrations, $p<0.01$ ( $t$ test, two-tailed).

$\ddagger$ Significance compared to maternal concentrations, $p<0.001$ ( $t$ test, two-tailed).

Table 2. $K_{m f}$ (across in situ perfused rat placenta), $D$, and $K_{m f} / D$ values for $\mathrm{Mg},{ }^{45} \mathrm{Ca}$, and ${ }^{51} \mathrm{Cr}$-EDTA*

\begin{tabular}{lccc}
\hline & $\begin{array}{c}\mathrm{K}_{\mathrm{vf}}(n=21) \\
\left(\mu \mathrm{L} \cdot \mathrm{min}^{-1} \cdot \mathrm{g}^{-1}\right)\end{array}$ & $\begin{array}{c}\mathrm{D}(n=6) \\
\left(\mathrm{cm}^{2} \cdot \mathrm{s}^{-1} \times 10^{6}\right)\end{array}$ & $\begin{array}{c}\mathrm{K}_{\mathrm{mf}} / \mathrm{D} \\
\left(\mathrm{cm} \cdot \mathrm{g}^{-1}\right)\end{array}$ \\
\hline $\mathrm{Mg}$ & $26.7 \pm 9.2$ & $6.9 \pm 0.7$ & 64.8 \\
${ }^{45} \mathrm{Ca}$ & $93.1 \pm 29.8$ & $7.6 \pm 0.5$ & 204.2 \\
${ }^{51} \mathrm{Cr}-$ EDTA & $3.2 \pm 0.9$ & $6.8 \pm 0.7$ & 7.8 \\
\hline
\end{tabular}

* Data are shown as mean $\pm \mathrm{SD}$. 


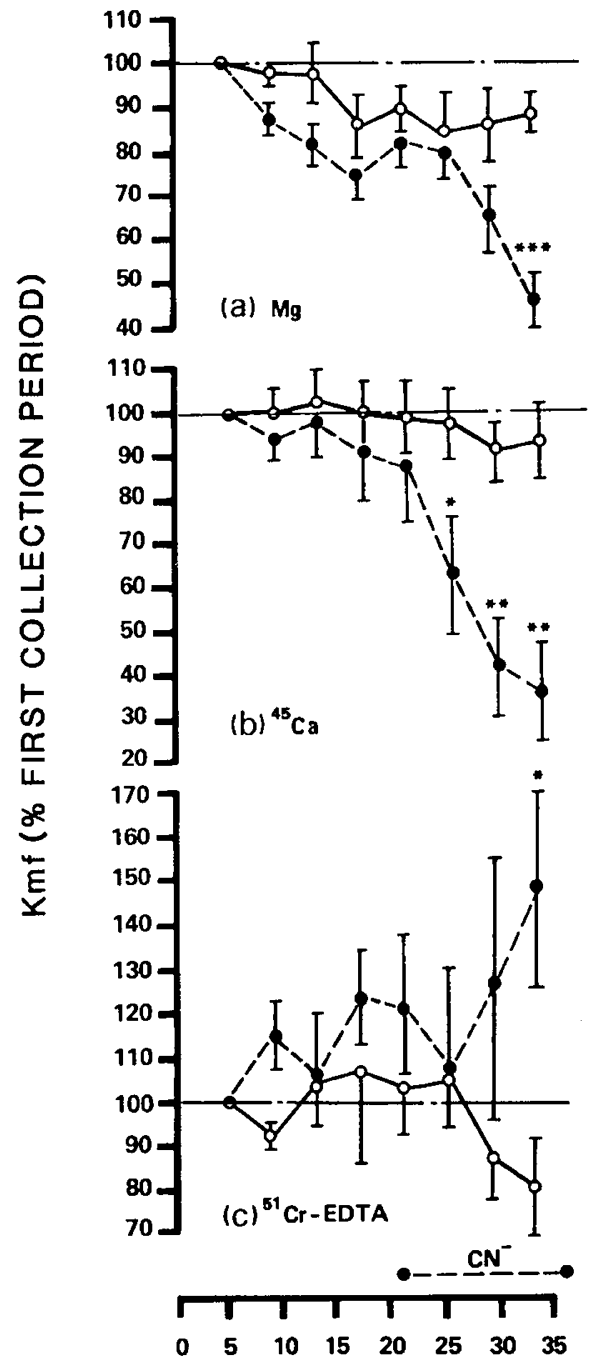

TIME AFTER ISOTOPE INJECTION (min.)

Fig. 1. Effects of adding $\mathrm{KCN}$ to fetal perfusate $(1 \mathrm{mmol} / \mathrm{L}$ final concentration) on $\mathrm{K}_{\mathrm{mf}}$ for $(a) \mathrm{Mg},(b){ }^{45} \mathrm{Ca}$, and $(c){ }^{51} \mathrm{Cr}$-EDTA. Mean $\mathrm{K}_{\mathrm{mf}}$ values $\pm \mathrm{SEM}$ are normalized to that for the first collection period ( $n=6 /$ group). Statistical significance between treated $(\bullet)$ and control (O) groups: ${ }^{*}, p<0.05 ;{ }^{* *}, p<0.01 ;{ }^{* * *}, p<0.001$ ( $t$ test, two-tailed).

(Fig. 3). In contrast, $\mathrm{K}_{\mathrm{mf}}{ }^{51} \mathrm{Cr}$-EDTA did not significantly change during the time course of this experiment (data not shown).

\section{DISCUSSION}

In our study, both total and ultrafiltrable plasma $\mathrm{Mg}$ concentrations were lower in pregnant compared with nonpregnant rats (Table 1). Lowered plasma $\mathrm{Mg}$ concentrations have been reported previously in pregnant rats (1) and rabbits (3), the latter study suggesting that this may partly reflect maternofetal $\mathrm{Mg}$ transfer. Studies in humans, however, suggest that a decrease in maternal plasma $\mathrm{Mg}$ concentration during pregnancy is related to a dilutional process inasmuch as plasma protein and $\mathrm{Mg}$ concentrations were correlated (14). In agreement with previous studies $(1,2)$, both total and ultrafiltrable $\mathrm{Mg}$ concentrations in maternal plasma were also lower than in fetal plasma (Table 1). This transplacental gradient, in the absence of a transplacental $\mathrm{Pd}$, favors an active mechanism for the maternofetal transfer of $\mathrm{Mg}$.

$\mathrm{K}_{\mathrm{mf}}$ values for ${ }^{45} \mathrm{Ca}$ and ${ }^{51} \mathrm{Cr}$-EDTA measured across the in situ rat placenta perfused using Mg-free fetal Ringer solution (Table 2) are comparable to those previously described in which $\mathrm{Mg}$ was present $(7,9,15)$. This suggests that removal of $\mathrm{Mg}$ from

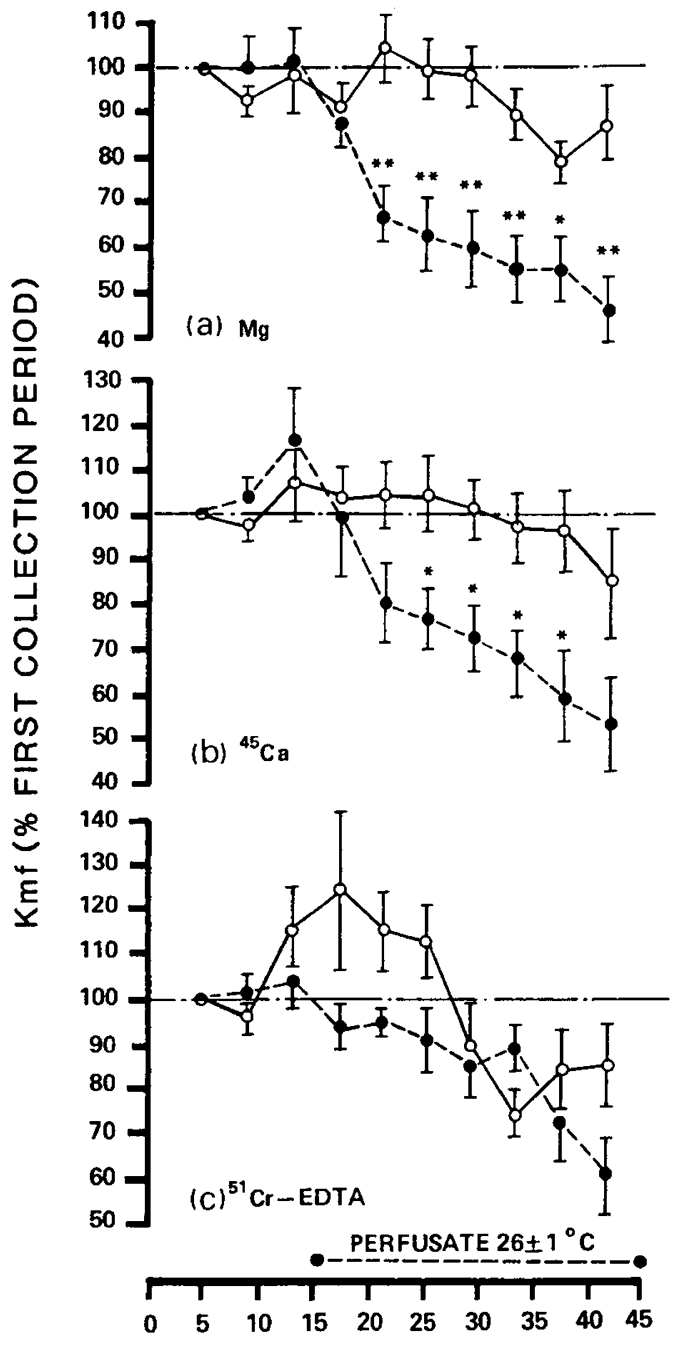

TIME AFTER ISOTOPE INJECTION (min.)

Fig. 2. Effects of lowering perfusate temperature from $37 \pm 1{ }^{\circ} \mathrm{C}$ to $26 \pm 1{ }^{\circ} \mathrm{C}$ on $\mathrm{K}_{\mathrm{mf}}$ for $(a) \mathrm{Mg},(b){ }^{45} \mathrm{Ca}$, and $(c){ }^{51} \mathrm{Cr}$-EDTA. Mean $\mathrm{K}_{\mathrm{mf}}$ values $\pm \mathrm{SEM}$ are normalized to that for the first collection period $(n=$ $6 /$ group). Statistical significance between treated $(\bullet)$ and control $(O)$ groups: ${ }^{*}, p<0.05 ;{ }^{* *}, p<0.01$ ( $t$ test, two-tailed).

the fetal perfusate does not increase paracellular permeability or affect placental $\mathrm{Ca}$ transfer, which is known to have an active component (9). ${ }^{51} \mathrm{Cr}$-EDTA was used as a paracellular diffusional marker (7) and, in the absence of flow limitation, $K_{m f}$ for such solutes across the rat placenta is a direct function of $D(16)$. The higher $\mathrm{K}_{\mathrm{mf}} / \mathrm{D}$ ratios found for $\mathrm{Mg}$ and ${ }^{45} \mathrm{Ca}$ compared with that for ${ }^{51} \mathrm{Cr}$-EDTA (Table 2) therefore suggest that transfer mechanisms are available for these cations in addition to paracellular diffusion. It should be noted that $\mathrm{K}_{\mathrm{mf}}$ values (and consequently $\mathrm{K}_{\mathrm{mf}} / \mathrm{D}$ ratios) for $\mathrm{Mg}$ and ${ }^{45} \mathrm{Ca}$ would have been even higher had they been calculated on the basis of the free maternal plasma electrolyte. Thus, $35 \%$ of maternal plasma $\mathrm{Mg}$ is nonfiltrable (Table 1) and this fraction, which is probably protein bound, may not be available for placental transfer.

$\mathrm{K}_{\mathrm{mf}} \mathrm{Mg}$ across the dually perfused rat placenta was twice that obtained across the in situ perfused preparation. This could partly reflect the absence of protein-bound $\mathrm{Mg}$ in the Krebs-Ringer solution used to perfuse the uterine artery in the dually perfused preparation, whereas in the in situ perfused preparation, $35 \%$ of the maternal plasma $\mathrm{Mg}$ concentration (used in the calculation of $\mathrm{K}_{\mathrm{mf}}$ ) is not filtrable and consequently may not be exchangable. However, in agreement with Mohammed et al. (10), $\mathrm{K}_{\mathrm{mf}} \mathrm{Cr}-$ EDTA was also greater in the dually perfused compared with the 


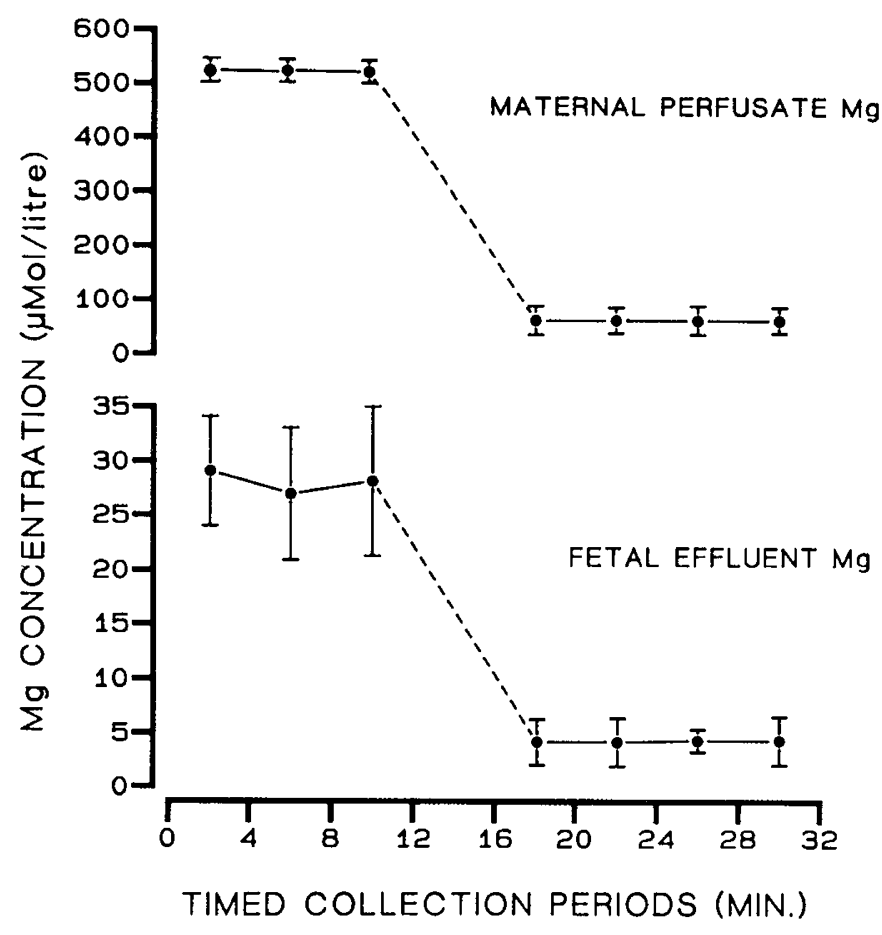

Fig. 3. Effects of reducing maternal perfusate $\mathrm{Mg}$ concentration on that in the fetal perfusate effluent in the dually perfused rat placental preparation. Data are shown as mean $\pm \operatorname{SEM}(n=4)$.

in situ perfused placenta, probably reflecting a greater permeability in the former preparation. In our study, a $90 \%$ decrease in the maternal perfusate $\mathrm{Mg}$ concentration was rapidly followed by a similar decrease in $\mathrm{Mg}$ concentration in the fetal perfusate effluent (Fig. 3). This suggests that $\mathrm{K}_{\mathrm{mf}} \mathrm{Mg}$ determined across the in situ perfused preparation largely reflects $\mathrm{Mg}$ transfer from maternal plasma and not simply elution of a placental $\mathrm{Mg}$ pool.

The finding that $\mathrm{K}_{\mathrm{mf}} \mathrm{Mg}$ and $\mathrm{K}_{\mathrm{mf}}{ }^{45} \mathrm{Ca}$ are both reduced after adding $\mathrm{KCN}$ to the fetal perfusate (Fig. 1) or lowering perfusate temperature (Fig. 2) suggests that the maternofetal transfer of these cations is at least partly dependent on placental metabolism. It is unlikely that these data reflect a decrease in placental permeability since $\mathrm{K}_{\mathrm{mf}}{ }^{51} \mathrm{Cr}$-EDTA was significantly increased by $\mathrm{KCN}$ and unaffected by perfusate temperature (Figs. 1 and 2). The effect of $\mathrm{KCN}$ on $\mathrm{K}_{\mathrm{mf}}{ }^{45} \mathrm{Ca}$ is consistent with that of $\mathrm{NaCN}$ and the metabolic inhibitor dinitrophenol previously described (9). These data could reflect direct effects on transcellular transport mechanisms for $\mathrm{Mg}$ and $\mathrm{Ca}$ or, alternatively, an indirect effect on a placental Pd. The magnitude and polarity of any transplacental $\mathrm{Pd}$ is not known although the maternofetal Pd between catheters placed in maternal and fetal extracellular space at sites removed from the placental exchange area has been reported to be $17 \mathrm{mV}$ fetus positive (17). The relationship between this and any transplacental Pd is not certain $(16,18)$, but a similar Pd with this polarity across the placenta could not drive maternofetal cation transfer. This suggests that the effects of the metabolic inhibitors resulted from direct actions on transport systems for $\mathrm{Mg}$ and $\mathrm{Ca}$.

Much evidence now exists for ATP-dependent maternofetal Ca transport $(16,19)$, and it is possible that $\mathrm{Mg}$ may compete for this system (8). However, studies by Mimouni et al. (20) suggest that maternofetal $\mathrm{Ca}$ transfer in the rat is unaffected by increasing maternal plasma $\mathrm{Mg}$ concentrations. Gunther et al. (21) reported that injection of amiloride or furosemide into pregnant rats at $19 \mathrm{~d}$ gestation reduced maternofetal transfer of an acute ${ }^{28} \mathrm{Mg}$ label within five $\mathrm{h}$. From these data, the authors suggested the presence of a placental $\mathrm{Na} / \mathrm{Mg}$ antiport and $\mathrm{Mg} /$ $\mathrm{HCO}_{3}$ symport, respectively. This clearly needs further investigation.

Acknowledgment. The authors thank Dr. W. G. Bardsley for his assistance with computation of diffusion coefficients.

\section{REFERENCES}

1. Dancis J, Springer D, Cohlan SQ 1971 Fetal homeostasis in maternal malnutrition. 11. Magnesium deprivation. Pediatr Res 5:131-136

2. Vormann J, Gunther T 1986 Development of fetal mineral and trace element metabolism in rats with normal as well as magnesium and zinc deficient diets. Biol Trace Elem Res 9:37-53

3. Kriesten K, Palawinskas R, Sommer H 1984 Magnesium levels in the body fluids of dam and fetal rabbits during the reproductive phase. Comp Biochem Physiol 79A:197-200

4. Care AD, Pickard DW, Weatherley A 1979 The measurement of transplacental magnesium fluxes in sheep. Res Vet Sci 27:121-122

5. Gupta MM, Kuppuswamy G, Subramanian AR 1982 Transplacental transfer of 25-hydroxy-cholecalciferol. Postgrad Med 58:408-410

6. Paunier L, Girardin NE, Brioschi PA, Beguin F 1987 Maternal-fetal relationship of extra and intracellular magnesium and potassium concentration. In Altura BM, Durlach J, Seelig MS (eds) Magnesium in Cellular Processes and Medicine. Karger, Basel, pp 151-155

7. Robinson NR, Atkinson DE, Jones CJP, Sibley CP 1988 Permeability of the near-term rat placenta to hydrophilic solutes. Placenta 9:361-372

8. Levine BS, Coburn JW 1984 Magnesium, the mimic/antagonist of calcium. N Engl J Med 310:(10):1253-1255

9. Stulc J, Stulcova B 1986 Transport of calcium by the placenta of the rat. J Physiol 371:1-16

10. Mohammed T, Stulc J, Sibley CP, Glazier J, Boyd RDH 1989 Evidence for carrier mediated potassium transfer across the dually perfused rat placenta. Placenta 10(5):517-518(abstr)

11. Mughal MZ, Shaw AJ, Sibley CP 1989 Evidence for active maternal-fetal transfer of magnesium across the in situ perfused rat placenta. J Physio 417:32P(abstr)

12. Fantel AG 1975 Fetomaternal potassium relations in the fetal rat on the twentieth day of gestation. Pediatr Res 9:527-530

13. Berhe A, Bardsley WG, Harkes A, Sibley CP 1987 Molecular charge effects on the protein permeability of the guinea pig placenta. Placenta $8: 365-380$

14. Girardin E, Beguin F, Brioschi PA, Paunier L 1987 Evaluation of serum and intracellular $\mathrm{Mg}$ and $\mathrm{K}$ concentrations during normal pregnancy. In: Altura BM, Durlach J, Seelig MS (eds) Magnesium in Cellular Processes and Medicine Karger, Basel, pp 156-163

15. Mughal MZ, Ross R, Tsang RC 1989 Clearance of calcium across in situ perfused placentas of intrauterine growth-retarded rat fetuses. Pediatr Res 25(4):420-422

16. Sibley CP, Boyd RDH 1988 Control of transfer across the mature placenta. In: Clarke JR (ed) Oxford Reviews of Reproductive Biology, Vol 10. Oxford University Press, New York, pp 382-435

17. Mellor DJ 1969 Potential differences between mother and foetus at different gestational ages in rat, rabbit and guinea-pig. J Physiol 204:395-405

18. Faber JJ, Thornburg KL 1983 Placental Physiology. Raven Press, New York

19. Fisher GJ, Kelly LK, Smith CH 1987 ATP-dependent calcium transport acros basal plasma membranes of human placental trophoblast. Am J Physiol 252: C1-C9

20. Mimouni F, Hammond G, Mughal MZ, Ross R, Tsang RC 1988 Pediatr Res 23(part 2):248A(abstr)

21. Gunther T, Vormann J, Hollriegl V 1988 Effects of amiloride and furosemide on ${ }^{28} \mathrm{Mg}$ transport into fetuses and maternal tissues of rats. Magnesium Bull $10: 34-37$ 